\title{
Plasma serotonin levels in Italian Fresian dairy cows
}

\author{
G. Bruschetta • P. Di Pietro • L. Sanzarello • \\ E. Giacoppo • A. M. Ferlazzo
}

Published online: 7 May 2010

(C) Springer Science+Business Media B.V. 2010

\begin{abstract}
The aim of this work was to investigate the metabolism of plasma serotonin or 5hydroxytryptamine (5-HT), an important neurotransmitter, in Fresian dairy cows, a breed of zootechnical interest, using high-performance liquid chromatography with electrochemical detection. The subjects under study were at the stage of early lactation $(n=10$; mean body weight $375 \pm 50 \mathrm{~kg}$; average age of 3 years; body condition score 2.5 ), bred in a farm at an altitude of $150 \mathrm{~m}$ a.s.l. To evaluate animal welfare on this farm, which is closely connected to an animal's physiological status, tryptophan and cortisol levels (measured by enzyme-linked immunosorbent assay), together with levels of certain blood components [total proteins (TP), albumin, creatinine, glucose (Glu), triglycerides, phospholipids, total cholesterol, and aspartate transaminase, measured by spectrophotometry] were analyzed. The results obtained are discussed in comparison with reference values, taking into account the environmental living conditions. Measured plasma serotonin concentrations, which were lower than values reported for Brown Swiss dairy cows of a comparable age and diet, appeared to be affected by breed, temperature, blood sampling season, and altitude. Additional differences between the levels of plasma tryptophan, the amino acid precursor of serotonin, of the two breeds were comparable. Negative correlations between plasma tryptophan and plasma cortisol levels $(r=-0.83, P<0.005)$, plasma serotonin and plasma TP levels $(r=-0.72, P<0.05)$, or Glu levels $(r=-0.77, P<$ 0.05 ) highlight the existence of a stress condition, which is connected to an energetic deficit related to lactation.
\end{abstract}

Keywords Fresian dairy cows $\cdot$ Plasma serotonin $\cdot$ Biochemical parameters $\cdot$ Tryptophan

$\overline{\text { G. Bruschetta }(\bowtie) \cdot \text { P. Di Pietro }}$ L. Sanzarello • A. M. Ferlazzo

Department of Morphology, Biochemistry, Physiology and Animal Production-Biochemistry Unity, University of Messina Polo Universitario dell'Annunziata, 98168 Messina, Italy

e-mail: giubruschetta@inwind.it

E. Giacoppo

Department of Morphology, Biochemistry, Physiology and Animal Production-Physiology Unity,

University of Messina Polo Universitario dell'Annunziata, 98168 Messina, Italy 


\section{Abbreviations \\ 5-HT Serotonin \\ MAO monoamino oxidase}

\section{Introduction}

Serotonin or 5-hydroxytryptamine (5-HT) is a neurotransmitter of the central and peripheral nervous system and is involved in many important biological functions, still incompletely understood. 5-HT acts as a vasoconstrictor on lung smooth muscles, the cardiovascular system, and cerebral arteries. It is synthesized from the amino acid tryptophan (Try) in the brain, mastocytes, and enterochromaffin cells of the gut. Ninety-seven percent of the total body amount of 5-HT is held in platelets (Andres et al. 1993), which do not synthesize it, but function as the main transporter into peripheral blood. In mammary glands, serotonin plays a role as a regulator of the short-term homeostasis of milk yield (Stull et al. 2007). In fact, mammary glands stimulated by prolactin (PRL) expressed essential genes for serotonin biosynthesis. Tryptophan hydroxylase mRNA increased during pregnancy and lactation with consequent 5-HT found in mammary gland epithelial cells and in milk (Matsuda et al. 2004). Plasma 5-HT, which has a rapid turnover distinct from that of platelet $5-\mathrm{HT}$, is the fraction which shows the equilibrium state between synthesis by enterochromaffin cells, the inactivation by liver and lung monoamino oxidase (MAO), and platelet uptake. Its role is still unclear. 5-HT has been deeply investigated only in humans during physiological (Hirvonen et al. 2002) and pathological conditions (Lee et al. 2000). Plasma 5-HT levels of Brown Swiss dairy cows measured by ELISA were previously reported (Kollmann et al. 2008). The aim of this work was to further investigate the metabolism of plasma serotonin (5-HT) in a breed of zootechnical interest, the Italian Fresian, which is used for milk production. Through the use of a more sensible methodology, HPLC with coulometric detection, together with the analysis of some blood and hormonal parameters, we were able to underline the animal welfare and/or existence of some possible stress conditions that may impair reproductive performance and milk production.

\section{Materials and methods}

The research was carried out on N.10 Italian Fresian dairy cows during early lactation (mean body weight $375 \pm 50 \mathrm{~kg}$; average age of 3 years; BCS 2.5). Cows were bred on a farm in Messina at an altitude of $150 \mathrm{~m}$ above sea level, were freely stabled, and were fed a mixed ration of concentrates $(50 \%)$ and fresh forages $(50 \%)$. Blood samples were collected into EDTA-containing collection vessels from the jugular vein at 9:00 a.m. after conventional milking at temperatures of $10-15^{\circ} \mathrm{C}$ in February. Following haematocrit (HCT \%) measurements, aliquots were centrifuged at $2000 \times g$ and the following plasma parameters were evaluated: total proteins (TP), albumin (ALB), creatinine (Crea), glucose (Glu), triglycerides (TG), phospholipids (PLP), total cholesterol (TCho), and aspartate transaminase (AST) by spectrophotometry. Cortisol levels, in duplicate, were measured by ELISA (Radim). The remaining fraction was centrifuged at $4500 \times g$ to obtain platelet poor plasma (PPP). The same volumes of N-methylserotonin (internal standard) and protein precipitation reagent (Chromsystems) were added to $100 \mu \mathrm{l}$ of each sample. The solutions were vortex-mixed, incubated at $4^{\circ} \mathrm{C}$, and centrifuged at $13000 \mathrm{rpm}$. The supernatant was used for the detection of plasma 5-HT and tryptophan (Try) by reverse phase HPLC (Waters 
Table 1 Blood parameters (Mean \pm S.D.) in Fresian dairy cows

\begin{tabular}{lllllllll}
\hline HCT (\%) & $\begin{array}{l}\text { Glu } \\
(\mathrm{mg} / \mathrm{dl})\end{array}$ & $\begin{array}{l}\text { PLP } \\
(\mathrm{mg} / \mathrm{dl})\end{array}$ & $\begin{array}{l}\text { TCho } \\
(\mathrm{mg} / \mathrm{dl})\end{array}$ & $\begin{array}{l}\text { TG } \\
(\mathrm{mg} / \mathrm{dl})\end{array}$ & $\begin{array}{l}\text { AST } \\
(\mathrm{U} / \mathrm{l})\end{array}$ & $\begin{array}{l}\text { Crea } \\
(\mathrm{mg} / \mathrm{dl})\end{array}$ & $\begin{array}{l}\text { TP } \\
(\mathrm{g} / \mathrm{dl})\end{array}$ & $\begin{array}{l}\text { Alb } \\
(\mathrm{g} / \mathrm{dl})\end{array}$ \\
\hline $22 \pm 2.1$ & $63 \pm 4.6$ & $173 \pm 30$ & $120 \pm 30$ & $61 \pm 26$ & $66 \pm 9$ & $1.27 \pm 0.22$ & $6.61 \pm 0.41$ & $2.54 \pm 0.18$ \\
\hline
\end{tabular}

1525 binary HPLC pump) with an electrochemical detector (ESA) and an experimental time of $16 \mathrm{~min}$. Statistical analyses used the Student's paired $t$-test and correlation and linear regression tests.

\section{Results and discussion}

Blood parameters (Table 1) were comparable with those previously reported for the same breed (Giuliotti et al. 2004) and highlight a condition of good health, good fitting to the environment, and an absence of peculiar clinical signs, therefore suggesting a general state of welfare. Albumin levels in some subjects were slightly lower. Triglyceride concentrations were higher in all subjects and were probably related to diet. Plasma serotonin, tryptophan, and cortisol levels were measured in Fresian dairy cows and were compared with previous data from Brown Swiss dairy cows (Kollmann et al. 2008) (Table 2).

The subjects of both breeds had a comparable average age and were fed an isoenergetic diet. The differences between the 5-HT values that were obtained by different methodologies were probably related to factors such as breed, season of sample taking, specifically winter time for Fresian and summer time for Brown Swiss, and eventually differences in altitude. In both human and animals, altitude may affect hypoxia conditions with consequential pulmonary hypertension. Among mammals, the first clinical signs of hypoxic pulmonary hypertension came from investigations carried out on bovines, which then became the first animal model for the study of this pathology (Rhodes 2005). Moreover, experiments carried out on hypoxic rats highlighted a decrease in serotonin uptake in platelets (Awabdy et al. 2003). At higher altitudes, platelet function could be underregulated resulting in higher plasma serotonin levels. Also differences between the two breeds of plasma tryptophan, the amino acid precursor of serotonin, were comparable and followed the same trend. The negative correlation between plasma tryptophan and cortisol $(\mathrm{r}=-0.83, \mathrm{P}<0.005)$ highlights, as we already know in humans (Ventura and Zeneroli 1982), the presence in bovines of an opposite trend of these two parameters. Cortisol levels remarkably higher than normal values (Medica et al. 2007) point out the presence of a physiological stress condition connected to an energetic deficit related to lactation. This hypothesis is confirmed by the BCS

Table 2 Plasma serotonin (5-HT), tryptophan (Try), and cortisol levels (Mean \pm S.D.) in dairy cows

\begin{tabular}{llll}
\hline BREED & 5-HT $(\mathrm{ng} / \mathrm{ml})$ & Try $(\mu \mathrm{g} / \mathrm{ml})$ & Cortisol (ng/ml) \\
\hline Fresian & $170 \pm 50$ & $3.73 \pm 1.23$ & $59.5 \pm 16.4$ \\
Brown Swiss $^{\mathrm{a}}$ & $334 \pm 81$ & $5.72 \pm 0.60$ & \\
\hline
\end{tabular}

\footnotetext{
${ }^{a}$ Kollmann et al. 2008
} 
values, the presence of significant negative correlations between tryptophan and cortisol levels $(\mathrm{r}=-0.83, \mathrm{P}<0.005), 5-\mathrm{HT}$ and TP $(\mathrm{r}=-0.72, \mathrm{P}<0.05)$, and 5-HT and glucose $(\mathrm{r}=$ $-0.77, \mathrm{P}<0.05)$, and at the limit of significance between 5-HT and HCT $(\mathrm{r}=-0.69, \mathrm{P}=$ 0.05 ). The subject of this study will be further investigated with the same breed and additional parameters related to energetic and mineral status (NEFA, $\beta-\mathrm{HB}, \mathrm{Ca}, \mathrm{P}$ ) will be analyzed in a greater number of subjects and during different lactation stages.

Acknowledgments We thank Cavallaro Farm of Zafferia for supplying blood samples. This research was carried out by PRA Young Researchers 2004 and PRA 2005 funds-University of Messina.

\section{References}

Andres AH, Rao ML, Ostrowitzki S, Entzian W (1993) Human brain cortex and platelet serotonin2 receptor binding properties and their regulation by endogenous serotonin. Life Sci 52:313-321

Awabdy D, Bryan-Lluka LJ, Wanstall JC (2003) 5-Hydroxytryptamine and platelets: uptake and aggregation in hypoxic pulmonary hypertensive rats. Eur J Pharmacol 459(1):1-7

Giuliotti L, Goracci J, Benvenuti MN, Facdouelle I, Profumo A (2004) Blood parameters: potential welfare indicators in dairy cows. Vet Med Faculty Annals-Pisa 57:281-289

Hirvonen J, Lindeman S, Joukamaa M, Huttunen P (2002) Plasma catecholamines, serotonin and their metabolites and beta-endorphin of winter swimmers during one winter. Possible correlations to psychological traits. Int J Circumpolar Health 61:363-372

Kollmann MT, Locher M, Hirche F, Eder K, Meyer HHD, Bruckmaier RM (2008) Effects of tryptophan supplementation on plasma tryptophan and related hormone levels in heifers and dairy cows. Dom Anim Endocrinol 34:14-24

Lee MS, Cheng FC, Yeh HZ, Liou TY, Liu JH (2000) Determination of plasma serotonin and 5hydroxyindoleacetic acid in healthy subjects and cancer patients Clin Chem 46:422-423

Matsuda M, Imaoka T, Vomachka AJ, Gudelsky GA, Hou Z, Mistry M, Bailey JP, Nieport KM, Walther DJ, Bader M, Horseman ND (2004) Serotonin regulates mammary gland development via an autocrineparacrine loop. Dev Cell 6(2):193-203

Medica P, Fazio E, Cusumano F, Messineo C, Ferlazzo A (2007) Risposta corticosurrenalica e tiroidea allo stress da mungitura meccanica in bovine pezzate rosse e meticce. SO.F.I.VET. National Congress 7:55-58

Rhodes J (2005) Comparative physiology of hypoxic pulmonary hypertension: historical clues from brisket disease. J Applied Physiol 98:1092-1100

Stull MA, Pai V, Vomachka AJ, Marshall AM, Jacob GA, Horseman ND (2007) Mammary gland homeostasis employs serotonergic regulation of epithelial tight junctions. Proc Natl Acad Sci USA 104 (42): 16708-16713

Ventura E, Zeneroli ML (1982) Encefalopatia epatica. In: Pezzuoli G, Spina GP Progressi Clinici Chirurgia. Piccin 1:154 